\title{
UPAYA PERDAMAIAN PROSES PERCERAIAN MELALUI MEDIASI OLEH PENGADILAN AGAMA SEBAGAI FAMILY COUNSELING
}

\author{
Al Fadili \\ Program Studi Ilmu Kesejahteraan Sosial FISIP Universitas Jember \\ alfadiliokay@gmail.com \\ Mahfudz Sidiq \\ Program Studi Ilmu Kesejahteraan Sosial Universitas Jember \\ S3 Manajemen Pendidikan Islam. \\ fudzdiq2@gmail.com
}

\begin{abstract}
One of the social problems in Jember is the high divorce rate. Divorce is chosen because it is considered as a solution to the problems that previously occurred in the family. On the other hand, many studies have shown that divorce could bring negative effects on husbands, wives and children. It means that divorce not only brings the positive effects because it ends the previous problem but also raises new problems. Therefore, it needs family counseling agencies that can help to solve the problem. Religious court is not a family counseling institution but in practice, it has effort to reconcile and resolve family problems through mediation, so it is important to understand the mediation effort of divorce in religious court as family counseling. This research used qualitative approach in descriptive type. The research location was in Religious Court of Jember. The used informant determination technique was Purposive technique. The used data collection methods were observation, interviews, and documentation. The data were analyzed by using Miles and Huberman model. The research results indicated that the mediation of divorce in religious court was an effort to solve family problems done by both busband and wife assisted by neutral and professional third party that was mediator. He did not take decision, but he helped families reach reconciliation. The mediation process was carried out with a problem solving approach with several steps, namely (1) establishing relationships with clients (2) identifying family problems, (3) doing caucus as needed, (4) giving advice, (5) offering reconciliation through written agreement, and (6) making formal agreement.
\end{abstract}

Keywords: divorce, family counseling, and mediation 


\section{Al Fadili, Mahfudz Sidiq}

\section{Abstrak}

Salah satu masalah sosial di Jember adalah tingginya angka perceraian. Perceraian dipilih karena dianggap sebagai solusi atas permasalahan yang sebelumnya terjadi dalam keluarga. Di sisi lain, banyak penelitian menunjukkan bahwa perceraian dapat berdampak negatif bagi suami, istri, dan anak. Artinya, perceraian tidak hanya membawa dampak positif karena mengakhiri masalah sebelumnya tetapi juga menimbulkan masalah baru. Oleh karena itu, diperlukan lembaga konseling keluarga yang dapat membantu menyelesaikan masalah tersebut. Pengadilan Agama bukanlah lembaga konseling keluarga tetapi dalam praktiknya memiliki upaya untuk mendamaikan dan menyelesaikan masalah keluarga melalui mediasi, sehingga penting untuk memahami upaya mediasi perceraian di pengadilan agama sebagai konseling keluarga. Penelitian ini menggunakan pendekatan kualitatif dengan tipe deskriptif. Lokasi penelitian di Pengadilan Agama Jember. Teknik penentuan informan yang digunakan adalah teknik Purposive. Metode pengumpulan data yang digunakan adalah observasi, wawancara, dan dokumentasi. Analisis data menggunakan model Miles dan Huberman. Hasil penelitian menunjukkan bahwa mediasi perceraian di pengadilan agama merupakan upaya penyelesaian masalah keluarga yang dilakukan oleh suami dan istri dengan dibantu pihak ketiga yang netral dan profesional sebagai mediator. Dia tidak mengambil keputusan, tetapi dia membantu keluarga mencapai rekonsiliasi. Proses mediasi dilakukan dengan pendekatan pemecahan masalah dengan beberapa langkah, yaitu (1) menjalin hubungan dengan klien (2) mengidentifikasi masalah keluarga, (3) melakukan kaukus sesuai kebutuhan, (4) memberi nasihat, (5) menawarkan rekonsiliasi melalui kesepakatan tertulis, dan (6) membuat kesepakatan formal.

\section{Kata Kunci : Perceraian, Konsuling Keluarga, Mediasi}

\section{Pendahuluan}

Membangun rumah tangga adalah kebutuhan dasar manusia, karena manusia tidak dapat hidup sendiri dan selalu butuh kasih sayang dari orang terdekat yakni keluarga, agar hidup menjadi lebih berarti, dan dapat melanjutkan keturunan untuk mencapai kebahagiaan. Namun, kenyataannya tidak semua rumah tangga yang dibangun melalui pernikahan menjadi rumah tangga utuh sesuai dengan harapan. Tidak 
Vol. 12, No. 1, April 2019

p-ISSN:2086 -0749

e-ISSN:2654-4784

sedikit pernikahan yang dilakukan berujung pada perceraian.

Di Indonesia perceraian merupakan masalah serius, dilihat dari angkanya yang meningkat secara fluktuatif setiap tahunnya diukur dari tahun 2009. Masalah berikutnya adalah penyumbang angka perceraian terbesar di Indonesia pada awal tahun 2016 adalah Provinsi Jawa Timur, sebagaimana dinyatakan Parawansa (selaku Menteri Sosial RI.) bahwa dalam beberapa tahun terakhir angka perceraian di Indonesia melonjak drastis dan Jawa Timur merupakan penyumbang terbesar dalam kasus perceraian di tanah air. Bahkan, mencapai 47\% atau hampir separuh kasus perceraian di Indonesia ada di Jawa Timur ${ }^{1}$.

1Parawansa. 2016. Harian Kompas. Online, Mensos: Jatim Penyumbang Terbesar Perceraian di Indone-
Masalah ini semakin jelas, saat diketahui bahwa tingginya angka perceraian di Jawa Timur itu sebagian besar disumbang oleh beberapa kabupaten, salah satunya adalah Jember. Jember adalah kabupaten yang memiliki kasus perceraian tinggi di setiap tahunnya. Berdasarkan jumlah pemohonnya saja di tahun 2015, Jember sudah menempati posisi ke-4 skala nasional, setelah Indramayu, Malang, dan Banyuwangi ${ }^{2}$. Angka perceraiannya juga demikian tinggi, tahun 2015, Kabupaten Jember mencapai 6.108 kasus.

Beberapa fenomena dan menjadi faktor penyebab perceraian di Jember di antaranya; permasalahan ekonomi, hubungan tidak harmonis, pasangan kurang

sia.htp:/ / regional.kompas.com/ read/2016/03 L20/1925/5241/ Mensos.Jatim.Penyumbang.Terbesar.Perceraian di Indonesia/. Tanggal 16 April 2016 2http://www. penanusantara.net/ diakses pada tanggal 6 April 2016 


\section{Al Fadili, Mahfudz Sidiq}

bertanggung jawab, gangguan dari pihak ketiga, perselingkuhan, cemburu, kekerasan dalam rumah tangga (KDRT), dan lain sebagainya.

Ketika problem keluarga terjadi secara terus menerus dan tidak menemukan solusi, maka salah satu solusi terakhir yang muncul pada pemikiran anggota keluarga adalah bercerai. Dapat diamati bahwa harapan mereka adalah untuk menghentikan masalah keluarga yang terus menerus terjadi, sehingga perceraian terlihat membawa aspek positif, karena dengan bercerai mereka menjadi lepas dari masalah keluarga yang sebelumnya terjadi.

Di sisi lain, banyak penelitian membuktikan, seperti temuan Ningrum ${ }^{3}$, bahwa perceraian tidak hanya membawa dampak positif, tetapi juga selalu membawa dampak negatif bagi

${ }^{3}$ Ningrum, P. R. "Perceraian Orang Tua dan Penyesuaian Diri Remaja". Diterbitkan. Jurnal. Psikologi, 2013. suami istri seperti traumatis, stres, rasa sedih, kecewa, frustasi, tidak tentram, dan khawatir untuk membangun rumah tangga kembali. Temuan Estuti ${ }^{4}$, menunjukkan bahwa dampak negatif juga dapat dialami anak seperti kecewa, trauma, cenderung memiliki masalah perilaku, dan kehilangan figur teladan. Oleh karena itu diperlukan lembaga konseling keluarga, yang dapat memberikan pertimbangan dan pengetahuan tentang konsekuensi perceraiannya, kemudian membantu mereka menyelesaikan permasalahannya.

Kondisi di lapangan, sudah tidak ada lagi bantuan bagi keluarga, yang sebelumnya dilakukan oleh Badan Penasihatan Pembinaan dan Pelestarian Perkawinan (BP4), karena surat keterangan penasihatan yang sebe-

${ }^{4}$ Estuti, W. T, "Dampak Perceraian Orang Tua terhadap Tingkat Kematangan Emosi Anak Kasus Pada 3 Siswa Kelas VIII SMP Negeri 2 Pekuncen Banyumas Tabun Ajaran 2012/2013." Tidak Diterbitkan. Skripsi. Semarang: FIP Universitas Negeri Semarang, 2013.

\section{4 | Pusat Studi Gender dan Anak (PSGA) LP2M IAIN Jember}


lumnya menjadi alasan masyarakat meminta nasihat di BP4, sekarang sudah tidak lagi menjadi syarat dalam mengurus cerai di pengadilan agama, sehingga masyarakat dapat mengurus cerai secara langsung di Pengadilan Agama tanpa melalui lembaga konseling apapun 5

Di sisi lain, pengadilan agama bukan lembaga konseling keluarga, tetapi dalam praktiknya berusaha mendamaikan keluarga yang mengurus cerai melalui proses mediasi, sehingga mediasi yang dilakukan oleh pengadilan agama merupakan satu-satunya upaya terakhir dalam membantu keluarga menyelesaikan masalah.

Berdasarkan fenomena dan hasil observasi awal di atas, maka permasalahan yang telah diuraikan adalah bagaimanakah upaya

${ }^{5}$ Observasi awal peneliti di lapangan, tanggal 15 April, 2016 perdamaian proses perceraian melalui mediasi oleh pengadilan agama sebagai family counseling? Tujuannya adalah ingin mendeskripsikan, dan menganalisis secara mendalam upaya perdamaian proses perceraian melalui mediasi oleh pengadilan agama sebagai family counseling.

\section{Metode Penelitian}

Penelitian ini menggunakan pendekatan kualitatif, jenisnya deskriptif, dan lokasi penelitian di Pengadilan Agama Jember. Teknik penentuan Informan dilakukan secara teknik purposive dengan menetapkan 10 informan. Teknik pengumpulan data melalui; observasi terus terang dan tersamar, wawancara informal dan menggunakan petunjuk umum, serta dokumentasi tentang (pedoman pelaksanaan mediasi, taha- 


\section{Al Fadili, Mahfudz Sidiq}

pan mediasi, surat permohonan/gugatan cerai, kode etik mediator, contoh laporan hasil mediasi, dan bentuk-bentuk kesepakatan perdamaian). Analisis data menggunakan model Miles and Huberman $^{6}$ yaitu tahap reduksi data, display data, dan kesimpulan/verifikasi. Uji keabsahan data, menggunakan triangulasi sumber dan metode.

\section{Hasil Penelitian Dan Pembahasan}

Mediasi perceraian di pengadilan agama adalah upaya penyelesaian permasalahan keluarga yang dilakukan oleh kedua pihak (suami-istri), dibantu oleh pihak ketiga netral profesional yakni mediator, yang dalam praktiknya tidak mengambil keputusan tetapi berusaha menyelesaikan masalah dan mengusahakan kesepakatan-kesepakatan damai. Medi-

${ }^{6}$ Miles and Huberman dalam Sugiyono, Memahami Penelitian Kualitatif. Cet.11. Bandung: Alfabeta, 2015), 91. asi ini dikatakan sebagai family counseling, karena kliennya adalah keluarga dengan masalah-masalah rumah tangga, difasilitasi oleh tenaga profesional dalam hal ini mediator, dan upayanya dilakukan dengan pendekatan pekerjaan sosial (problem solving approach), dengan 6 tahapan, yaitu:

a. Membangun relasi dengan klien;

Pada tahap ini mediator membangun hubungan dengan kedua pihak karena kemungkinan besar kedua pihak dapat merasa asing dan tertutup kepada mediator, karena pada tahap ini merupakan pertemuan pertama kali. Padahal dalam mediasi kedua pihak perlu terbuka agar dapat mengungkapkan masalahnya, dan menerima masukan mediator.Tahap ini dilakukan oleh mediator dengan memperkenalkan diri, menjelaskan tentang definisi mediasi, prosedur mediasi, peran mediator, netralitas mediator dan juga kerahasiaan mediasi. Ke- 
Vol. 12, No. 1, April 2019

p-ISSN:2086 -0749

e-ISSN:2654-4784

rahasiaan mediasi dijelaskan agar kedua pihak paham bahwa mediasi sifatnya rahasia, sehingga harapannya kedua pihak dapat terbuka dari awal hingga akhir tanpa khawatir aibnya diketahui oleh orang lain. Kerahasiaan juga merupakan prinsip dasar dalam konseling. Proses membangun relasi inilah yang dalam family counseling disebut engagement.

b. Mengidentifikasi masalah keluarga;

Tahap ini penting karena proses berikutnya sangat bergantung pada teridentifikasinya masalah di tahap ini. Tujuannya adalah untuk menelusuri, mengetahui, dan memperdalam apa saja masalah yang menjadi penyebab keluarga menginginkan perceraian. Identifikasi masalah keluarga ini dilakukan dengan dua cara: Pertama, melalui dokumen-dokumen kedua pihak. Seperti buku nikah, surat permohonan/surat gugatan cerai, yang di dalamnya berisi informasi tentang data-data pribadi kedua pihak, termasuk permasalahan keluarga yang melatarbelakangi kedatangannya di pengadilan agama. Kedua, melalui interview secara langsung dengan kedua pihak. Yakni mediator memberikan pertanyaanpertanyaan mendetail tentang kondisi rumah tangga, dan semua permasalahan yang terjadi sebelumnya dalam rumah tangga. Contoh sudah berapa lama berumah tangga, sudah pisah rumah berapa bulan, penyebab ingin cerai, kenapa begitu, dan lain sebagainya. Dalam family counseling, proses identifikasi masalah disebut assessment. Assessment adalah tahap praktisi menggali dan mengetahui masalah secara mendalam disertai dengan penyebabpenyebabnya, nantinya dari per- 


\section{Al Fadili, Mahfudz Sidiq}

masalahan yang diketahui dapat dijadikan bahan dari praktisi untuk dapat mengatasinya.

Wibhawa $^{7}$ menyatakan bahwa Assessment (diagnosis) merupakan tahap dimana praktisi mengkaji dan menilai mengapa penyebab-penyebab persoalan tersebut muncul. Kemudian juga mengkaji langkah-langkah apa yang sebaiknya dilakukan dalam mengatasi permasalahan tersebut. Berdasarkan pemahaman tentang assessment di atas, maka inilah pentingnya interview dalam proses identifikasi masalah keluarga. Semua informasi yang telah diketahui sebelumnya melalui dokumen dapat dilakukan crosscheck kebenarannya dan diperdalam kembali oleh mediator.

7Wibhawa, B., Raharjo, S. T., S, Meilanny B. Dasar- Dasar Pekerjaan Sosial, Pengantar Profesi Pekerjaan Sosial (Bandung: Widya Padjajaran, 2010), 66.
Zastrow $^{8}$, menyatakan bahwa tahap identifikasi masalah disebut dengan assessment, yang mana dilakukan dengan cara mengumpulkan, mengorganisasikan, dan menginterpretasikan informasi berupa masalah dan kebutuhan klien. Dari proses pengidentifikasian masalah tersebut, mediator dapat melihat permasalahan keluarga semakin jelas, sehingga dapat melanjutkan mediasi pada tahap berikutnya.

c. Melakukan kaukus jika diperlukan;

Salah satu kondisi yang dapat terjadi dalam proses mediasi adalah adanya hal penting yang tersembunyi dan tidak dapat disampaikan kepada mediator. Hal ini bisa dikarenakan informasi tersebut merupakan hal sensitif yang berkaitan dengan pihak lawan, sehingga terasa tidak baik jika disampaikan di depan pihak terse-

${ }^{8}$ Zastrow, C, Introduction to Social Work \& Social Welfare-Empowering People. Tenth Edition, (USA: Linda Shreiber, 2010), 66. 
but. Atau bisa dikarenakan informasi yang ingin disampaikan adalah rahasia diri sehingga hanya mediator yang diharapkan dapat mendengar.

Dalam kondisi seperti ini terdapat teknik yang namanya kaukus. Kaukus adalah pertemuan yang diadakan oleh mediator dengan kedua pihak secara terpisah, yaitu dengan cara memberikan kesempatan kepada klien pertama misalkan pihak suami terlebih dahulu untuk melakukan pertemuan dengan mediator di ruang mediasi, kemudian pihak istri. Melalui pertemuan kaukus ini, mediator dapat melakukan proses identifikasi masalah dan mengetahui keinginan klien. Adapun teknisnya dilakukan secara bergantian dengan durasi waktu yang sama, misalkan pihak pertama kaukus-nya 15 menit, demikian juga pihak kedua.
Dalam family counseling ini dinamakan dengan individual session. Zastrow ${ }^{9}$ menyatakan bahwa pertemuan secara terpisah (individual session) ini perlu dilakukan jika salah satu pihak menginginkan pembicaraan yang menyangkut pasangan lain, dan tidak dapat disampaikan karena memperhatikan kondisi emosional yang akan muncul.

Dengan kaukus, akan didapatkan manfaat, sebagaimana Sholevar ${ }^{10}$, menyatakan bahwa pertemuan secara terpisah (Individual session) dapat dilakukan karena memberikan keuntungan berupa turunnya perlawanan atau penyangkalan dari masing-masing pasangan, menurunkan penahanan terhadap pihak lain untuk

${ }^{9}$ Zastrow, C, Introduction ...... 186.

10Sholevar, G. P., Textbook Of Family And Couples Therapy-Clinical Applications (Washington: American Psychiatric Publishing, 2003), 422. 


\section{Al Fadili, Mahfudz Sidiq}

mengungkapkan, dapat membantu dalam membuka informasi rahasia, dan membantu kedua pihak untuk lebih mampu melakukan introspeksi diri.

d. Memberikan nasihat;

Tahap ini sangat penting karena mediator berusaha menyelesaikan masalah keluarga. Dilakukan dengan 5 cara: 1) Mengedukasi; yaitu mediator memberikan pemahaman kepada kedua pihak tentang tujuan pernikahan, dan tanggung jawab suami dan juga istri. Menurut Fuller dalam Astarini ${ }^{11}$, bagian ini merupakan bentuk dari fungsi mediator yakni sebagai educator (pendidik), yakni memberikan pemahaman bagi kedua pihak agar cara pandangnya terhadap masalah menjadi lebih baik, dan dapat lebih terbuka dengan masukan mediator untuk berdamai. 2)

\footnotetext{
${ }^{11}$ Astarini, D. R. S., Mediasi Pengadilan, Salab Satu Bentuk Penyelesaian Sengketa Berdasarkan Asas Peradilan Cepat, Sederhana, Biaya Ringan. Edisi Pertama (Bandung: PT. Alumni, 2013), 94.
}

Memberikan nasihat spesifik pada masalahnya; Tujuannya agar mereka dapat lebih baik dalam menyikapi masalahnya. Misalnya masalah sifat tidak cocok maka mediator memberikan nasihat untuk menyikapi masalah tersebut sebagai hal yang wajar, sehingga suami istri harus pandai-pandai saling menyesuaikan diri. Karena mediasi ini dilaksanakan di pengadilan agama, dan orang-orang yang berperkara juga merupakan warga beragama Islam, maka beberapa nasihat yang diberikan juga dari sudut pandang agama Islam. Seperti misalnya masalah kurangnya ekonomi, maka mediator menasihati untuk sabar, menerima kondisi sulit sebagai ujian hidup dari Allah, dan berusaha mencoba mencari pekerjaan tambahan lain dengan dibantu istri. Selain itu mediator juga menambahkan nasihatnya dengan memberikan contoh keluarga tokoh agama yang diteladani oleh seluruh umat Islam, karena juga pernah berada 
dalam permasalahan yang sama bahkan lebih sulit tetapi dapat bertahan dan menerima kondisi tersebut dengan baik, dapat bersyukur dan tidak ingin bercerai.

Dalam permasalahan kekerasan rumah tangga, mediator menasihati dengan memberitahu hukum dari melakukan kekerasan seperti memukul istri, bahwa memukul istri itu merupakan bentuk kekerasan dalam rumah tangga (KDRT), dan itu tidak baik karena tidak menyelesaikan permasalahan. Yang baik adalah dengan cara mengingatkan.

Hal ini sesuai dengan penjelasan idealnya peran mediator sebagaimana dijelaskan oleh Casals ${ }^{12}$, yang mana menjelaskan bahwa mediator harus berusaha membantu kedua pihak mengubah

${ }^{12}$ Casals, M., M., "Divorce Mediation In Europe: An Introductory Outline. "Electronic Journal of Comparative Law, 2005. permusuhan dan kebencian yang dirasakan, menjadi interaksi yang membangun, positif, dan optimis demi kebaikan bersama. Dalam hal ini mediator memberitahu tentang buruknya kondisi yang telah terjadi, dan mediator memberitahu bagian-bagian yang perlu diperbaiki dari kesalahan-kesalahan tersebut.

Untuk keluarga yang ingin bercerai karena sering bertengkar karena sifat-sifat yang tidak cocok, termasuk seperti tutur kata yang kurang baik, maka mediator memberikan nasihat untuk terus berusaha saling menyesuaikan diri, saling mengalah, saling memaafkan dan saling menasihati.

Usaha mediator dalam menasihati kedua pihak untuk masalah di atas, merupakan bentuk dari penjelasan Casals $^{13}$ bahwa

\footnotetext{
${ }^{13}$ Casals, M., M, 'Divorce Mediation........
} 


\section{Al Fadili, Mahfudz Sidiq}

dalam mediasi perceraian, mediator berusaha untuk membantu kedua pihak dengan mencoba mengubah kualitas interaksi dan komunikasi kedua pihak.

Mediator juga menambahkan bahwa apapun masalah yang terjadi dalam keluarga baik berupa sikap suami atau istri seperti tutur kata, cara memperlakukan dan sebagainya yang tidak sesuai sehingga sering memunculkan emosi dan menimbulkan pertengkaran, perselisihan, maka mediator memberikan nasihat untuk mengendalikan diri saat emosi, jangan sampai mengeluarkan katakata yang kurang pantas karena dapat menyakiti hati istri. Nasihat mediator dalam hal ini merupakan bentuk dari penjelasan Casals ${ }^{14}$, yang menyatakan bahwa inilah salah satu tugas mediator yang juga harus berusaha membantu kedua pihak untuk berkomunikasi dengan cara yang lebih baik. 3)

\footnotetext{
${ }^{14}$ Casals, M., M., "Divorce Mediation
}

Memberitahu dampak negatif perceraian bagi anak; Selain nasihat di atas, terdapat nasihat mediator berikutnya yang selalu diberikan kepada semua suami istri yang perceraiannya dilatarbelakangi oleh masalah apapun. Dengan memberitahu konsekuensi yang akan didapatkan jika mereka memilih bercerai, berupa dampak negatif perceraian yang dapat di alami oleh anak. Nasihat ini diberikan jika mereka memiliki anak. Harapan mediator agar mereka dapat menjadikan gambaran dampak negatif ini sebagai pertimbangan penting dalam mengambil keputusan. Dampak negatif yang digambarkan oleh mediator adalah anak yang orang tuanya bercerai akan mengalami gangguan secara psikologis, mental, dan kepribadian yang semuanya berpengaruh kepada masa depan anak. Anak yang seharusnya menjadi harapan orang tua, menjadi mengkhawatirkan masa depannya karena orang tua bercerai. 
Mediator juga menambahkan nasihat berdasarkan fakta bahwa anak dalam rumah tangga yang bercerai selain dapat terganggu psikisnya, juga akan sulit menemukan jati dirinya karena tidak adanya panutan dan contoh dari keduanya dalam rumah tangga. Mediator juga memberikan tambahan nasihat dari sudut pandang agama bahwa anak adalah harapan orang tua tidak hanya di dunia, tetapi juga akhirat, karena anak yang sholeh dan sholehah adalah harapan orang tua agar dapat membantu mendoakan orang tua nanti saat orang tua sudah meninggal.

Nasihat berupa gambaran dampak negatif bagi anak, dijelaskan oleh Casals ${ }^{15}$ bahwa salah satu upaya mediator untuk menyelesaikan permasalahan keluarga tion........ adalah dengan memberikan gambaran kondisi yang dapat terjadi sebagai risiko jika kedua pihak tidak dapat berdamai dan tidak menemukan kesepakatan. Ini yang juga disebut dengan skenario yang mungkin terjadi.

Berdasarkan penjelasan dalam tahap ini, maka dapat disimpulkan bahwa dalam proses mediasi, mediator memberikan nasihat dengan berusaha: (1) Mengedukasi kedua pihak, (2) Membantu kedua pihak untuk berkomunikasi dengan lebih baik, (3) Mengubah kualitas interaksi antara kedua pihak, (4) Berusaha mentransformasikan kondisi emosi kedalam interaksi konstruktif, (5) Membantu kedua pihak menyelesaikan permasalahannya termasuk dengan memberikan solusi konkrit, (6) Membantu kedua belah pihak melihat perceraian sebagai salah satu alternatif dan 


\section{Al Fadili, Mahfudz Sidiq}

bukan satu-satunya alternatif, (7) Membantu memberikan gambaran/prediksi konsekuensi perceraian berupa dampak negatif pada anak.

Nasihat mediator tentang gambaran dampak negatif tersebut menjadi penting karena kondisi anak dengan orang tua yang bercerai akan mudah dimengerti oleh semua pihak, sehingga memungkinkan untuk benar- benar berpikir tentang keinginannya untuk bercerai. Tujuannya dapat membantu kedua belah pihak berusaha berdamai dan memperbaiki keluarga.

Zastrow $^{16}$ menyatakan bentuk-bentuk intervensi dalam praktik pekerjaan sosial diantaranya; pertama, memunculkan langkah atau tindakan, untuk mencapai tujuan yang telah dirumuskan sebelumnya. Kedua, menerapkan intervensi pencegahan dengan meningkatkan kapabilitas klien.

${ }^{16}$ Zastrow, C, Introduction ...... 66
Ketiga, membantu klien mengatasi masalah- masalahnya. Keempat menegosiasikan, memediasi, dan melakukan advokasi terhadap hakhak diri klien. Kelima, memfasilitasi masa-masa transisi akhir dari intervensi.

Dengan demikian, dpat dipahami bahwa langkah mediator dalam memberikan nasihat kepada kedua pihak merupakan suatu bentuk intervensi (intervention) karena merupakan bentuk upaya praktisi (mediator). 4) Menerapkan intervensi pencegahan dan juga peningkatan kapasitas kedua pihak. Dalam hal ini berupa nasihat-nasihat tentang konsekuensi perceraian bagi kedua pihak untuk mencegah terjadinya risiko negatif pasca perceraian. Nasihat ini juga meningkatkan kapasitas kedua pihak dalam memahami permasalahan keluarga dan dampak perceraian. Termasuk nasihat mediator tentang cara menyikapi permasalahan keluarga menjadi bagian dari peningkatan kapasitas kedua 
Vol. 12, No. 1, April 2019

p-ISSN:2086 -0749

e-ISSN:2654-4784

belah pihak. 5) Menyelesaikan permasalahan klien. Saran yang diberikan mediator secara spesifik, merupakan solusi agar permasalahan tersebut tidak terulang kembali.

e. Menawarkan kesepakatan damai melalui perjanjian tertulis;

Setelah diberikan nasihat pada tahap sebelumnya, pihak yang ingin bercerai belum berpikir untuk damai, dan pihak yang akan dicerai ingin mempertahankan rumah tangganya. Maka pada tahap ini mediator memunculkan solusi untuk berdamai yang ditawarkan kepada kedua pihak dengan menyusun kesepakatan damai melalui perjanjian secara tertulis.

Perjanjian tertulis tersebut adalah kesanggupan dari pihak yang bersalah untuk berjanji bahwa kedepannya akan memperbaiki dan tidak akan mengulangi kesalahan yang sebelumnya dilakukan, demi rumah tangga, dan agar pihak yang ingin menceraikan dapat membatalkan keinginannya. Jika pihak yang tidak mau damai setuju dengan janji secara tertulis yang ditawarkan, maka perjanjiannya dapat dibuat, disesuaikan dengan permintaan pihak yang tidak mau damai. Akhirnya jika semua perjanjiannya sama-sama disepakati bersamaoleh kedua belah pihak, maka mediasi dikatakan berhasil, dan keluarga menjadi damai atau tidak jadi cerai.

Setiap permohonan cerai selalu diawali dari permasalahan oleh salah satu anggota keluarga baik suami atau istri, maka secara teknis sebelum mediator menawarkan kesepakatan damai melalui perjanjian tertulis, mediator selalu mengawalinya dengan bertanya kepada pihak yang keberatan un- 


\section{Al Fadili, Mahfudz Sidiq}

tuk bercerai. Pertanyaannya adalah kalau memang pihak pertama (misalnya suami) benar-benar keberatan dan ingin kembali berdamai dengan pihak kedua (istri), apakah si suami benarbenar sanggup melakukan segala sesuatu demi diterima istri.

Jika suami menyatakan bahwa dia siap melakukan apapun demi keutuhan rumah tangga, maka mediator akan menawarkan kepada istri untuk kembali bersatu dengan suami. Dalam hal ini, mediator juga menawarkan kepada istri untuk menuliskan apa saja syarat yang diinginkan oleh istri untuk dapat memaafkan suami dan dapat menerima suami kembali dalam kehidupan istri.

Dengan demikian dapat dipahami bahwa alternatif penyelesaian yang diusulkan oleh mediator adalah menawarkan kesepakatan damai melalui perjanjian tertulis. berdasarkan opsi tersebut, mediator berharap kedua belah pihak dapat menyelesaikan masalahnya, dan dapat berdamai. Widyana dalam Astarini ${ }^{17}$, menyatakan bahwa secara umum, mediator tidak membuat keputusan, tetapi hanya membantu dan memfasilitasi para pihak yang bersengketa untuk merumuskan berbagai opsi penyelesaian sengketa yang dapat diterima oleh keduanya, sehingga dapat dipahami bahwa ini merupakan salah satu peran mediator dalam mediasi.

Berbagai macam syarat atau permintaan dari salah satu pihak misalnya istri, agar disanggupi oleh suami (atau sebaliknya). Hal ini tergantung pada permasalahan yang terjadi dalam rumah tangga yang menyebabkan keinginan istri untuk bercerai.

Beberapa contoh di antaranya, istri mengajukan gugatan cerai untuk suaminya dikarenakan suami melakukan pernikahan sirri dengan orang lain, maka setelah

${ }^{17}$ Astarini, D. R. S., Mediasi Pengadilan,........ 92 . 
Vol. 12, No. 1, April 2019

p-ISSN:2086 -0749

e-ISSN:2654-4784

dilakukan mediasi oleh mediator, pada tahap ini istri mau rujuk dengan suami dengan syarat suami mau menceraikan istri kedua.

Terkadang pihak yang mengajukan cerai tidak dapat merumuskan apa yang diinginkan dari pihak yang keberatan, untuk dijadikan syarat damai. Dalam kondisi seperti ini, mediatorlah yang berinisiatif memunculkan solusi berupa tawaran-tawaran kepada pihak yang mengajukan cerai, sesuai dengan permasalahan.

Langkah mediator dalam memunculkan inisiatif solusi di atas, merupakan bentuk dari penjelasan Kovach dalam Amriani18, menyatakan bahwa salah satu tahap dalam mediasi adalah mediator berusaha mengajukan usulan

${ }^{18}$ Amriani, N., Mediasi, Alternatif Penyelesaian Sengketa Perdata di Pengadilan. Cetakan Ke-2. (Jakarta: PT RajaGrafindo Persada, 2012), 63. atau gagasan penyelesaian permasalahan.

Selain itu, dapat dipahami pula bahwa pada tahap ini, mediator: 1) berusaha membantu kedua pihak mencapai persetujuan Casals $^{19}$, 2) dengan mengemuka-kan pilihan penyelesaian sengketa, Astarini $^{20}$, 3) untuk menemukan solusi yang merupakan kepentingan terbaik untuk anak-anak mereka (SIU, 2007).

Inilah bentuk dari family counseling, dimana praktisi membantu kedua pihak untuk melihat perceraian bukan sebagai satusatunya alternatif tetapi masih ada alternatif lain (Sholevar ${ }^{21}$, karena praktisi dalam hal ini mediator membantu menawarkan alternatif solusi untuk masalahnya dengan

${ }^{19}$ Casals, M., M. "Divorce Mediation........

${ }^{20}$ Astarini, D. R. S, Mediasi Pengadilan,........ 103-110

${ }^{21}$ Sholevar, G. P...... 433-434 


\section{Al Fadili, Mahfudz Sidiq}

tetap mempertahankan rumah tangga yaitu melalui perjanjian tertulis.

f. Penyusunan kesepakatan formal;

Maksud mediasi ini adalah surat kesepakatan perdamaian berisi perjanjian yang disetujui oleh kedua pihak (suami dan istri). Dalam menyusun surat tersebut, mediator memfasilitasi kedua pihak untuk berunding dan menuliskan apa saja permintaan dari pihak yang mengajukan perceraian harus disanggupi oleh pihak yang keberatan, untuk dimasukkan dalam surat perjanjian. Kemudian dalam penyusunannya, mediator mendampingi kedua belah pihak, untuk menghindari tiga hal, kesepakatan yang ditulis yaitu:1) bertentangan dengan hukum, 2) bertentangan dengan kesejahteraan, 3) merugikan pihak lain.

Jika dari sekian isi kesepakatan yang dibuat, ditemukan ada poin yang bertentangan dengan tiga hal tersebut, maka mediator tidak akan membolehkan poin tersebut dicantumkan.

Setelah perjanjian disusun dan disepakati. Maka mediator membacakan isi perjanjiannya dari awal hingga akhir. Kemudian meminta kedua pihak menandatanganinya, diikuti tanda tangan mediator. Surat kesepakatan perdamaian yang telah ditandatangani tersebut, kemudian akan diberikan juga kepada kedua pihak sebagai hasil mediasi.

Dengan penyusunan kesepakatan formal ini, maka sesuai dengan apa yang dinyatakan Sholevar ${ }^{22}$, bahwa terapis membantu kedua pihak untuk melihat perceraian bukan satu-satunya alternatif, tetapi dapat diupayakan kesepakatan damai diantara kedua belah pihak.

Zastrow, ${ }^{23}$ juga menyatakan bahwa salah satu bentuk format penyelesaian masalah yang dilakukan oleh terapis yang beker-

22Sholevar, G. P. ......... 433-434.

23Zastrow, C. Introduction ...... 186. 
jasama dengan kedua pihak, dengan cara mengusahakan kesepakatan, sehingga melalui deretan proses ini, mediasi merupakan bentuk dari family counseling yang dilakukan oleh praktisi profesional dalam hal ini mediator untuk membantu keluarga yang memiliki masalah dan ingin bercerai, agar bersama-sama menemukan solusi dan kembali berdamai. Proses mediasinya dilakukan dengan pendekatan problem solving approach.

\section{Simpulan}

Berdasarkan hasil penelitian dan pembahasan terdahulu dapat ditarik kesimpulan bahwa mediasi perceraian di Pengadilan Agama adalah upaya penyelesaian masalah yang dilakukan oleh kedua pihak dibantu oleh pihak ketiga netral, disebut mediator, tidak mengambil keputusan, tetapi berusaha membantu keluarga memecahkan masalah dan mencapai kesepaka$\tan$ damai. Mediasi ini disebut family counseling, karena upaya bantuan ini adalah bentuk dari pekerjaan sosial level mezzo yang dilakukan oleh tenaga profesional yang telah terlatih yakni mediator, kliennya adalah keluarga dengan masalah rumah tangga, dan teknik yang digunakan dalam penanganannya adalah menggunakan pendekatan pekerjaan sosial yakni problem solving approach, dengan langkah-langkah sebagai berikut:

Menjalin relasi dengan klien. Dengan cara memperkenalkan diri, dan mengedukasi kedua pihak tentang mediasi dan juga kerahasiaan mediasi. Tujuannya agar kedua pihak dapat terbuka selama proses mediasi. Dalam family counseling, disebut engagemen Mengidentifikasi masalah keluarga. Dilakukan dua cara, yak- 


\section{Al Fadili, Mahfudz Sidiq}

ni melalui data keluarga yang telah terkumpul dan juga melalui interview kepada kedua belah pihak dalam pertemuan langsung. Dalam family counseling disebut assessment.

Melakukan kaukus jika diperlukan. Yaitu pertemuan terpisah yang diterapkan jika ada pihak yang sulit terbuka karena ada hal yang tersembunyi. Dalam family counseling disebut dengan individual session.

Memberikan nasihat. Dengan memberikan cara pandang positif terhadap masalah mereka, meluruskan pemahaman yang keliru, memberikan contoh cara menyikapi masalah dari sudut pandang agama, memberitahu konsekuensi perceraian dengan menggambarkan dampak negatif perceraian bagi anak. Tujuannya adalah agar semua nasihat menjadi pertimbangan kedua belah pihak dalam mengambil keputusan. Dalam family counseling, ini merupakan bentuk tahap intervensi.
Menawarkan kesepakatan damai melalui perjanjian tertulis. Yaitu dengan merumuskan kesanggupan pihak bersalah untuk berubah dan memperbaiki kesalahannya. Jika kedua belah pihak setuju dengan tawaran ini, maka suami istri dapat berdamai. Dalam family counseling ini juga merupakan bentuk intervensi.

Penyusunan kesepakatan formal. yaitu, mediator memfasilitasi kedua pihak berunding dan menyusun kesanggupannya. Setelah selesai, maka ditandatangani oleh kedua belah pihak, dan mediator, kemudian menjadi bukti hasil mediasi bagi keduanya. Surat perjanjian tertulis ini disebut kesepakatan perdamaian. Dalam family counseling disebut bentuk implementasi intervensi.

Dengan demikian novelty penelitin ini adalah tersedianya proses perdamaian melalui mediasi pengadilan agama sebagai "family counseling" dapat mem- 
An-Nisa' : Jurnal Kajian Perempuan \& Keislaman

Vol. 12, No. 1, April 2019

p-ISSN:2086 -0749

e-ISSN:2654-4784

perbaharuhi keharmonisan tata kehidupan rumah tangga.

\section{DAFTAR PUSTAKA}

Amriani, N, Mediasi, Alternatif Penyelesaian Sengketa Perdata di Pengadilan. Cetakan Ke-2. (Jakarta: PT Raja Grafindo Persada, 2012).

Astarini, D. R. S. Mediasi Pengadilan, Salab Satu Bentuk Penyelesaian Sengketa Berdasarkan Asas Peradilan Cepat, Sederhana, Biaya Ringan. Edisi Pertama. (Bandung: PT. Alumni, 2013).

Sholevar, G. P. Textbook Of Family And Couples Therapy - Clinical Applications. (Washington: American Psychiatric Publishing, Inc, . 2003).

Sugiyono. Memahami Penelitian Kualitatif. Cetakan Ke-11. (Bandung: Alfabeta, 2015).

Wibhawa, B., Raharjo, S. T., S, Meilanny B. Dasar- Dasar Pekerjaan Sosial, Pengantar Profesi Pekerjaan Sosial (Bandung: Widya Padjajaran, 2010).
Zastrow, C. Introduction to Social Work \& Social Welfare - Empowering People. Tenth Edition (USA: Linda Shreiber, 2010).

Casals, M., M. 2005. "Divorce Mediation In Europe: An Introductory Outline." Electronic Journal of Comparative Law.

Ningrum, P. R. 2013. "Perceraian Orang Tua Dan Penyesuaian Diri Remaja". Diterbitkan. Jurnal. Psikologi.

Internet:

Harian Kompas Online. 2016. Mensos: Jatim Penyumbang Terbesar Perceraian di Indonesia.

http://regional.kompas.co $\mathrm{m} / \mathrm{read} / 2016 / 03 / 20 / 19255$ 241/Mensos.Jatim.Penyum bang.Terbesar.Perceraian di Indonesia/. [16 April 2016]

Pena Nusantara. Jember Peringkat 4 Nasional Untuk Kasus Gugatan Perceraian.

http://www.penanusantara.net/je mber-peringkat-4-nasionaluntuk-kasus-gugatanperceraian/.[6 April 2016] 